\title{
Palladium-catalysed amination of 2-acyl-1-alkyl-5-bromopyrroles ${ }^{\text {is }}$
}

\author{
Isabel Castellote, Juan J. Vaquero and Julio Alvarez-Builla* \\ Departamento de Química Orgánica, Universidad de Alcalá, 28871-Alcaláde Henares, Madrid, Spain
}

Received 3 October 2003; revised 4 November 2003; accepted 10 November 2003

\begin{abstract}
The first intermolecular $\mathrm{C}-\mathrm{N}$ bond-forming reactions between substituted 2-bromopyrroles and primary and cyclic secondary amines were performed using $\mathrm{Pd}_{2}(\mathrm{dba})_{3}$ as catalyst with BINAP as the ligand. The aminations proceeded in the presence of $\mathrm{NaO}^{t} \mathrm{Bu}$ at $80-100^{\circ} \mathrm{C}$ in $31-93 \%$ yields.
\end{abstract}

(C) 2003 Elsevier Ltd. All rights reserved.

In conjunction with our recent work on the chemistry and biology of pyrrolodiazines ${ }^{1-4}$ we had to prepare a series of dihydropyrrolo[1,2-a]pyrazine derivatives of general structure 1 (Fig. 1). As it was envisaged that a palladium-catalysed amination of the appropriate haloheterocycle would provide the desired series, we needed to investigate the palladium-catalysed amination of the pyrrole moiety.

Although palladium-catalysed carbon-nitrogen bond formation using aryl halides has been extensively investigated in recent years, ${ }^{5-8}$ allowing the coupling of a great variety of amines with any halobenzene or haloazine, no broadly applicable methodology had been developed to prepare five-membered heterocycles ${ }^{9,10}$ until very recently when Hartwig reported the successful amination of halofurans, -thiophenes, -thiazoles, -oxazoles, -indoles and -benzimidazoles. ${ }^{11}$ However, the methodology was not extended to halopyrroles because of the instability of these substrates. Herein we wish to report our progress in the Pd-catalysed cross coupling reaction between functionalised 2-bromopyrroles $\mathbf{2}$ and 3 and a selection of primary and secondary amines.

As a starting point, it is noticeable that all our attempts to carry out the amination reaction between morpholine and either 2- or 3-bromopyrrole failed both with the

\footnotetext{
Keywords: Palladium; Catalysed; Amination; Functionalised; 2-Halopyrroles.

${ }^{2}$ Supplementary data associated with this article can be found, in the online version, at doi:10.1016/j.tetlet.2003.11.029

* Corresponding author. Tel.: +34-1-918854606; fax: +34-1-918854686; e-mail: julio.alvarez@uah.es
}

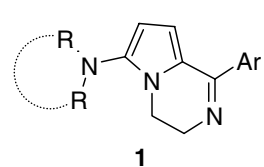<smiles>CC(=O)c1ccc(Br)n1C</smiles><smiles>Brc1ccc2n1CCN=C2c1ccccc1</smiles>

Figure 1.

parent heterocycle and a protected model (Me, TIPS). ${ }^{12}$ Thus we selected 2-acetyl-5-bromo-1-methylpyrrole $2^{13}$ as the simplest model to establish the most effective conditions for the $\mathrm{C}-\mathrm{N}$ bond formation.

Initially, the reaction between $\mathbf{2}$ and morpholine was tested using $\mathrm{Pd}_{2}(\mathrm{dba})_{3}$ as catalyst in the presence of different ligands such as dppf, BINAP, ${ }^{t} \mathrm{Bu}_{3}$ and biphenyl $\mathrm{P}^{t} \mathrm{Bu}_{2}$. Using a strong base such as $\mathrm{NaO}^{t} \mathrm{Bu}$ in THF, the dppf ligand failed to form any coupled product whereas in toluene $\mathrm{P}^{t} \mathrm{Bu}_{3}$ and biphenyl $\mathrm{P}^{t} \mathrm{Bu}_{2}$ produced low or moderate yields. Racemic BINAP appeared to be the ligand, which afforded the best yield ${ }^{14}$ in combination with $\mathrm{NaO}^{t} \mathrm{Bu}$ (weaker bases such as $\mathrm{CsCO}_{3}$ and $\mathrm{K}_{3} \mathrm{PO}_{4}$ were also tested) in toluene at $80^{\circ} \mathrm{C}$. Using the optimised conditions shown in Scheme 1 a variety of cyclic secondary amines (Table 1, entries 1-6) were successfully coupled with substrate 2 with yields shown in Table 1. However, when the above optimised conditions were applied to the coupling reaction of $\mathbf{2}$ and acyclic secondary amines such as di- $n$-butylamine, diphenylamine and dipropenylamine, no reaction was observed. An alternative study of the reaction conditions for the coupling of di- $n$-butylamine and $\mathbf{2}$ using the same ligands in combination with $\mathrm{Pd}(\mathrm{OAc})_{2}$ or $\mathrm{Pd}(\mathrm{dba})_{2}$ was also unsuccessful. 


$$
\text { (2) }
$$

Scheme 1.

Table 1. Palladium-catalysed amination of 2-acetyl-5-bromo-1-methylpyrrole (2)

\begin{tabular}{|c|c|c|c|}
\hline Entry & Amine & Coupling product (4) & Yield (\%) \\
\hline 1 & & & 73 \\
\hline 2 & & e & 65 \\
\hline 3 & & $\mathrm{M}$ & 93 \\
\hline 4 & 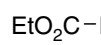 & & 85 \\
\hline 5 & & & 69 \\
\hline 6 & & e & 80 \\
\hline 7 & & Me & 0 \\
\hline 8 & & $\mathrm{Me}$ & 82 \\
\hline 9 & & $\mathrm{Me}$ & 48 \\
\hline 10 & & Me & 50 \\
\hline 11 & $D$ & & 45 \\
\hline 12 & & & 31 \\
\hline
\end{tabular}




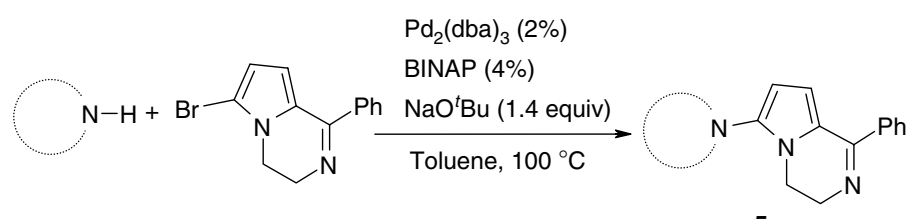

3

5

Scheme 2.

Table 2. Palladium-catalysed amination of 6-bromo-1-phenyl-3,4-dihydropyrrolo[1,2-a]pyrazine (3)

\begin{tabular}{|c|c|c|c|}
\hline Entry & Amine & Coupling product (5) & Yield $(\%)$ \\
\hline 1 & & & 69 \\
\hline 2 & & & 64 \\
\hline 3 & & & 69 \\
\hline 4 & & & 45 \\
\hline 5 & & & 43 \\
\hline 6 & & & 51 \\
\hline
\end{tabular}

In contrast with the lack of reactivity of di- $n$-butylamine, primary amines did react with $\mathbf{2}$ under the same conditions used for cyclic secondary amines, affording the corresponding coupled products in good (Table 1, entry 8) or moderate yields (Table 1, entries 9-12). ${ }^{15}$ These isolated yields were moderate at least in part because of the difficulties of isolation of the amines 4 (Table 1, entries 9-12).

The large difference in reactivity of substrate $\mathbf{2}$ with the selection of amines tested was also found with 6-bromo1-phenyl-3,4-dihydropyrrolo[1,2-a]pyrazine 3. ${ }^{16}$ In fact, this substrate only reacted with cyclic secondary amines, affording compounds 5 shown in Table 2. No acyclic secondary or primary amine reacted under the conditions employed for the successful coupling of cyclic secondary amines or under any of the other conditions tested $\left[\mathrm{Pd}(\mathrm{dba})_{2}\right.$ or $\mathrm{Pd}(\mathrm{OAc})_{2}$ and $\mathrm{P}^{t} \mathrm{Bu}_{3}$, ferrocenyl di-tert-butylphosphine, biphenyl $\mathrm{P}^{t} \mathrm{Bu}_{2}$ or $\left.\mathrm{dppf}\right]$, with substrate $\mathbf{3}$ being recovered unaltered or as the debrominated compound (Scheme 2). It is noteworthy that in this case the yields of amination using cyclic secondary amines were strongly dependent on the reaction tem- perature, with heating at $100^{\circ} \mathrm{C}$ (instead of $80^{\circ} \mathrm{C}$ used for substrate 2 ) affording the best isolated yields. ${ }^{17}$

In summary, we have studied the conditions for the amination of 6-bromo-1-phenyl-3,4-dihydro-pyrrolo[1,2-a]pyrazine using 2-acetyl-5-bromo-1-methylpyrrole as a simple model for the palladium-catalysed amination, which occurred in the presence of $\mathrm{Pd}_{2}(\mathrm{dba})_{3}$, BINAP and $\mathrm{NaO}^{t} \mathrm{Bu}$ in toluene at $80-100{ }^{\circ} \mathrm{C}$. This procedure allowed for, the first time, the amination of substituted 2-halopyrroles with cyclic secondary and primary amines. Work is in progress to extend this methodology to a variety of substituted 2- and 3-halopyrroles.

\section{Acknowledgements}

Financial support from the Comisión Interministerial de Ciencia y Tecnología (CICYT, project BQU2001-1508) is gratefully acknowledged. 


\section{References and notes}

1. Mínguez, J. M.; Castellote, M. I.; Vaquero, J. J.; García Navío, J. L.; Alvarez-Builla, J.; Castaño, O.; Andrés, J. L. J. Org. Chem. 1996, 61, 1655.

2. Mínguez, J. M.; Vaquero, J. J.; García Navío, J. L.; Alvarez-Builla, J. Tetrahedron Lett. 1996, 37, 4263.

3. Mínguez, J. M.; Castellote, M. I.; Vaquero, J. J.; García Navío, J. L.; Alvarez-Builla, J.; Castaño, O.; Andrés, J. L. Tetrahedron 1997, 53, 9341.

4. Minguez, J. M.; Vaquero, J. J.; Alvarez-Builla, J.; Castaño, O.; Andrés, J. L. J. Org. Chem. 1999, 64, 7788.

5. Hartwig, J. F. Angew. Chem., Int. Ed. 1998, 37, 2046.

6. Hartwig, J. F. Acc. Chem. Res. 1998, 31, 852.

7. Wolfe, J. P.; Wagaw, S.; Marcoux, J.-F.; Buchwald, S. L. Acc. Chem. Res. 1998, 31, 805.

8. Hartwig, J. F. In Modern Amination Methods; Ricci, A., Ed.; Wiley-VCH: Weinheim, Germany, 2000.

9. For aminations of thiophenes, see: (a) Watanabe, M.; Yamamoto, T.; Nishiyama, M. Chem. Commun. 2000, 133; (b) Luker, T. J.; Beaton, H. G.; Whiting, M.; Mete, A.; Cheshire, D. R. Tetrahedron Lett. 2000, 41, 7731; (c) Ogawa, K.; Radke, K. R.; Rothstein, S. D.; Rasmussen, S. C. J. Org. Chem. 2001, 66, 9067.

10. For amination of thiazoles and imidazoles, see: (a) Hong, Y.; Tanoury, G. J.; Wilkinson, S. H.; Bakale, R. P.; Wald, S. A.; Senanayake, C. H. Tetrahedron Lett. 1997, 38, 5607; (b) Wang, Z.; Rizzo, C. J. Org. Lett. 2001, 3, 565; (c) Schoffers, E.; Olsen, P. D.; Means, J. C. Org. Lett. 2001, 3, 4221.

11. Hooper, M. W.; Utsunomiya, M.; Hartwig, J. F. J. Org. Chem. 2003, 68, 2861.

12. This study was carried out before Hartwig's work in Ref. 11 was published.

13. Kim, E.-H.; Koo, B.-S.; Song, C.-E.; Lee, K.-J. Synth. Commun. 2001, 31, 3627.

14. Both racemic and $R-(+)$-BINAP give the same yields in the amination reaction.
15. General procedure for the reaction of 2 . An oven-dried glass vial was charged with 2 (1.0 $\mathrm{mmol}), 1.2 \mathrm{mmol}$ (entries $1-8,10$ ) or $3.0 \mathrm{mmol}$ (entries $9,11,12$ ) of the amine, $\mathrm{NaO}^{t} \mathrm{Bu}$ (1.4 mmol), $\mathrm{Pd}_{2}(\mathrm{dba})_{3}$ and $(0.02 \mathrm{mmol})$, and BINAP $(0.04 \mathrm{mmol})$, in dry toluene $(2 \mathrm{~mL})$ under argon. The flask was immersed in an oil bath heated at $80^{\circ} \mathrm{C}$ and stirred overnight. The solution was then allowed to cool to room temperature, taken up in $\mathrm{CH}_{2} \mathrm{Cl}_{2}(10 \mathrm{~mL})$, filtered over Celite and concentrated. Column chromatography of the residue on silica gel using EtOAc as eluent gave pure compounds 4 .

16. This compound was prepared (Castellote, I. Ph.D. Thesis, University of Alcalá, 2001) by bromination with NBS (1.5 mmol, $\mathrm{CH}_{2} \mathrm{Cl}_{2}$ ) of the corresponding 1-phenyl-3,4dihydropyrrolo[1,2-a]pyrazine, which was obtained following the method described by Flament, I.; Sonney, P.; Ohloff, G. Helv. Chim. Acta 1997, 60, 1872.

(3): $\mathrm{Mp} 84-86^{\circ} \mathrm{C}$; IR (KBr) $v_{\max }\left(\mathrm{cm}^{-1}\right): 2947,1589,1566$, $1408,1036 .{ }^{1} \mathrm{H}$ NMR $\left(300 \mathrm{MHz}\right.$, DMSO- $\left.d_{6}\right) \delta(\mathrm{ppm}) 7.72$ $7.69(\mathrm{~m}, 2 \mathrm{H}) ; 7.43-7.40(\mathrm{~m}, 3 \mathrm{H}) ; 6.37(\mathrm{~d}, 1 \mathrm{H}, J=4.0 \mathrm{~Hz})$; $6.23(\mathrm{~d}, 1 \mathrm{H}, J=4.0 \mathrm{~Hz}) ; 4.04-3.92(\mathrm{~m}, 4 \mathrm{H}) .{ }^{13} \mathrm{C} \mathrm{NMR}$ $\left(50 \mathrm{MHz}, \mathrm{CDCl}_{3}\right) \delta(\mathrm{ppm}) 159.8,137.5,128.4,128.3$, 125.8, 113.2, 110.8, 106.4, 48.0, 40.2; Anal. Calcd for $\mathrm{C}_{13} \mathrm{H}_{11} \mathrm{BrN}_{2} ; \mathrm{C}, 56.75 ; \mathrm{H}, 4.03 ; \mathrm{N}, 10.18$. Found: C, 56.49; $\mathrm{H}, 4.23 ; \mathrm{N}, 10.11$.

17. General procedure for the reaction of 3 . An oven-dried glass vial was charged with $3(1.0 \mathrm{mmol}), 1.2 \mathrm{mmol}$ of the amine, $\mathrm{NaO}^{t} \mathrm{Bu}(1.4 \mathrm{mmol}), \mathrm{Pd}_{2}(\mathrm{dba})_{3}$ and $(0.02 \mathrm{mmol})$, and BINAP $(0.04 \mathrm{mmol})$ in dry toluene $(2 \mathrm{~mL})$ under argon. The flask was immersed in an oil bath heated at $100^{\circ} \mathrm{C}$ and stirred overnight. The solution was then allowed to cool to room temperature, diluted with water $(15 \mathrm{~mL})$ and extracted with $\mathrm{CH}_{2} \mathrm{Cl}_{2}(3 \times 15 \mathrm{~mL})$. The organic phase was dried $\left(\mathrm{Na}_{2} \mathrm{SO}_{4}\right)$, concentrated in vacuo and the residue chromtographed on silica gel. Compounds 5 were isolated using $\mathrm{CH}_{2} \mathrm{Cl}_{2} / \mathrm{MeOH}$ (8:2) saturated with ammonia as eluent. 